\title{
Midbrain neurocysticercal granuloma appearing as "face of panda"
}

Figure Midbrain "face of panda" due to neurocysticercal granuloma

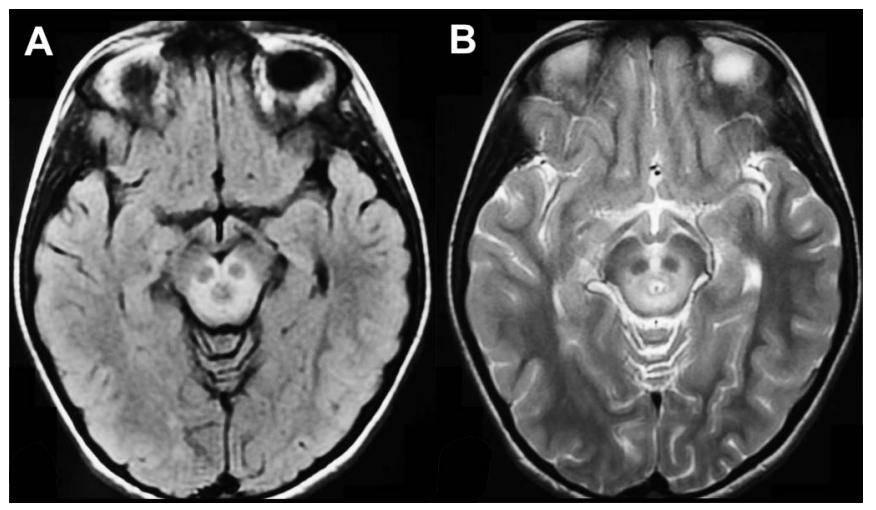

Axial fluid-attenuated inversion recovery (A) and T2-weighted (B) MRI of midbrain reveal a cyst with mural nodule, in the periaqueductal grey matter, ventral to the aqueduct. Edema involving the surrounding white matter, sparing the red nuclei and cerebral peduncles, is seen.

An 8-year-old girl presented with a 5-day history of double vision on attempting to look downward. Examination of her eye movements revealed weakness of bilateral superior oblique muscles, with a normal examination otherwise. The brain MRI revealed a cysticercal granuloma of the midbrain ventral to the cerebral aqueduct with perilesional edema, sparing both red nuclei, and giving the appearance of "face of panda" (figure, A and B). The face of panda sign has been described in cases of Wilson disease, including "face of giant panda" and "face of panda cub" in the midbrain and pons, respectively. ${ }^{1,2}$

Ramesh Konanki, DM, Dandu Ravi Varma, DM, Lokesh Lingappa, DM, Bhamy Hariprasad Shenoy, MD

From Rainbow Children's Hospital and Perinatal Centre (R.K., L.L.); Care Hospitals (D.R.V.); and LV Prasad Eye Institute (B.H.P.S.), Hyderabad, India.

Author contributions: R.K., L.L., and B.H.S. provided clinical care to the patient and drafted the manuscript. D.R.V. provided radiologic input.

Study funding: No targeted funding reported.

Disclosures: The authors report no disclosures relevant to the manuscript. Go to Neurology.org for full disclosures.

Correspondence to Dr. Konanki: rameshkonanki@gmail.com

1. Hitoshi S, Iwata M, Yoshikawa K. Mid-brain pathology of Wilson's disease: MRI analysis of three cases. J Neurol Neurosurg Psychiatry 1991;54:624-626.

2. Shivakumar R, Thomas SV. Face of the giant panda and her cub: MRI correlates of Wilson disease. Neurology 2009;72;e50. 


\section{Neurology}

\section{Midbrain neurocysticercal granuloma appearing as "face of panda" \\ Ramesh Konanki, Dandu Ravi Varma, Lokesh Lingappa, et al. \\ Neurology 2013;80;1999 \\ DOI 10.1212/WNL.0b013e318293e357}

This information is current as of May 20, 2013

\section{Updated Information \& Services}

References

Subspecialty Collections

Permissions \& Licensing

Reprints including high resolution figures, can be found at: http://n.neurology.org/content/80/21/1999.full

This article cites 2 articles, 2 of which you can access for free at: http://n.neurology.org/content/80/21/1999.full\#ref-list-1

This article, along with others on similar topics, appears in the following collection(s):

Diplopia (double vision)

http://n.neurology.org/cgi/collection/diplopia_double_vision MRI

http://n.neurology.org/cgi/collection/mri

Parasitic infections

http://n.neurology.org/cgi/collection/parasitic_infections

Information about reproducing this article in parts (figures,tables) or in its entirety can be found online at:

http://www.neurology.org/about/about_the_journal\#permissions

Information about ordering reprints can be found online:

http://n.neurology.org/subscribers/advertise

Neurology ${ }^{\circledR}$ is the official journal of the American Academy of Neurology. Published continuously since 1951, it is now a weekly with 48 issues per year. Copyright (O) 2013 American Academy of Neurology. All rights reserved. Print ISSN: 0028-3878. Online ISSN: 1526-632X.

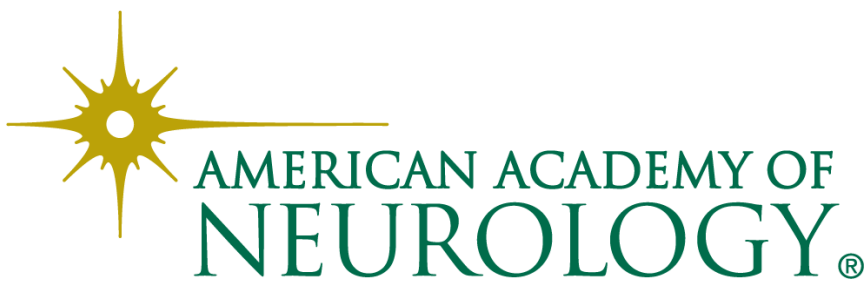

